\title{
Internacional escravista: a política da Segunda Escravidão
}

\author{
Rafael de Bivar Marquese e Tâmis Peixoto Parron
}

\section{RESUMO}

O artigo analisa a unificação das experiências políticas dos três grandes espaços escravistas da América do século XIX, Estados Unidos, Cuba e Brasil, após o surgimento da aliança do movimento abolicionista anglo-americano na década de 1830. Descrevendo o quadro político das três regióes, demonstra como elas passaram a reagir ao abolicionismo internacionalista de modo integrado e cooperativo, o que pode ser chamado de "internacional escravista". Examina, por fim, por que essa interação não evoluiu para uma plataforma oficial dos governos envolvidos. Seu desaparecimento ocorreu quando a Guerra Civil norte-americana (1861-65) abalou a escravidão no Brasil e no Império Espanhol.

Palavras-chave: Estados Unidos, Brasil, Cuba, escravidão, política.

\begin{abstract}
The article analyses the unification of the political experiences of the three major nineteenth-century New World slave societies (United States, Cuba, and Brazil) after the rise of the Anglo-American abolitionist alliance in the 1830s. Describing the political framework of those three zones, it shows how they reacted to the Anti-Slavery International abolitionism in an integrated and cooperative way, something that can be called the Proslavery International. Finally, it examines why this interaction has not evolved to an official platform of its respective governments. The Proslavery International disappearance occurred with the impact of the American Civil War (1861-1865) in the Brazilian and the Spanish Empire slave systems.
\end{abstract}

Keywords: United States, Brazil, Cuba, slavery, politics. 


\section{Impacto mundial da Guerra Civil}

Em janeiro de 1867, um polemista brasileiro simpatizante do protestantismo, no meio das diferenças que ajustava com um padre católico, fez uma análise em perspectiva global de um dos principais desafios do Segundo Reinado: conduzir o destino da escravidão negra no Brasil depois da Guerra de Secessão nos Estados Unidos (1861-65). No seu entender,

Brasil e Cuba conservavam a escravidão à sombra dos Estados Unidos; nação poderosa, a quem nenhum outro povo se atreveria a impor condição alguma de sua existência política. Mas enfim a questáo da escravidão foi discutida, disputada e condenada dentro do próprio país - ninguém lhe exigiu a liberdade dos escravos; foi a mesma nação que a decidiu; uma parte forçou a outra a ceder, e a escravidão desapareceu nos Estados Unidos; portanto no Brasil e em Cuba a escravidão não tem mais razão de ser - a questão é de tempo! ${ }^{1}$

Uma das razóes por que essas palavras surpreendem está na clareza, se não na crueza, de como elas explicitam os limites dos Estados independentes numa época ciosa da soberania nacional. Segundo o argumento do autor, Abreu e Lima, Brasil e Espanha, não sendo potências econômicas ou políticas, seriam incapazes de conter a pressão do abolicionismo internacional, devendo eles mesmos iniciar um processo legislativo de emancipação para adaptar-se à ordem mundial pós-Guerra Civil. A conjunção conclusiva "portanto", palavra-chave do trecho, supóe a escravidão negra oitocentista como uma instituição regulada no plano nacional, mas condicionada no internacional. É uma suposição precisa. Se quisessem ser soberanos no problema do cativeiro, esses Estados deviam começar reconhecendo os limites de sua própria soberania.

A leitura de Abreu e Lima não desapareceu com o século XIX. A historiografia sobre Cuba e Brasil também destaca, há um bom tempo, o impacto determinante da Guerra Civil sobre o início da crise da escravidão nos dois países. Para o caso das possessões espanholas, os historiadores mostram que o conflito, além de ter interditado de forma definitiva o tráfico transatlântico de escravos para a ilha caribenha, relacionou-se ao surgimento do movimento antiescravista em Porto Rico e na Espanha, à eclosão da primeira guerra de independência de Cuba e, conseqüentemente, ao processo que levou à aprovaçáo da Lei Moret, em $1870^{2}$. A respeito do Brasil, ressaltam como o evento estimulou diretamente o início dos debates que levaram à elaboração do projeto de libertação do ventre escravo, convertido em lei imperial em $1871^{3}$. Percebe-se, portanto, que, a despeito de se valerem de perspectivas teóricas e metodológicas distintas, os historiadores vêm construindo um relativo consenso sobre a centralidade do conflito norteamericano para o fim da escravidão em Cuba e no Brasil e, por extensão, no hemisfério ocidental.

O que se pode dizer é que ainda não foi sistematicamente explorado - desde os contemporâneos até as pesquisas recentes - o processo histórico que tornou uma guerra civil a Guerra Civil, fazendo um conflito circunscrito, doméstico, escalar para um evento de magnitude mundial, com desdobramentos imediatos sobre uma monarquia européia e um império americano. A historiografia mencionada no parágrafo anterior fornece parte do caminho para se compreender esse processo. Todavia, tratando de forma isolada as experiências brasileira e cubana, os especialistas não exploraram o quadro de forças mais amplo que formou a escravidão no espaço atlântico entre as décadas de 1820 e 1850 . Mesmo tentativas recentes de aquilatar a instituição em perspectiva mundial - como é o caso de Seymour Drescher - construíram narrativas que justapóem, em vez de integrar, as evoluçóes locais do cativeiro nos Estados Unidos, no Brasil e em Cuba, articulando-as pouco umas às outras e aos processos globais que as configuraram ${ }^{4}$. Um enquadramento que une dinâmica internacional e particularidades regionais sem tomar nenhum dos polos como unidades estáticas de análise, cremos, poderá fornecer uma via adequada para responder ao problema formulado.

Daí a validade heurística da categoria "Segunda Escravidão". Com esse conceito, o historiador Dale Tomich chama a atenção para a unificação das experiências históricas da República dos Estados Unidos 
da América, do Império do Brasil e da colônia espanhola de Cuba no século XIX. Usualmente tomado como o século da emancipação, esse período verificou em realidade o apogeu da escravidão negra no Novo Mundo, tanto do ponto de vista do número absoluto de escravos alocados nas plantations americanas, como do valor obtido com a exploração do trabalho deles. Como esclarece Tomich, "sob a aparente uniformidade da emancipação escrava no século XIX, encontramos trajetórias e resultados complexos e diferenciados que se podem remontar à posição dos sistemas escravistas particulares na economia mundial"s. De fato, as modificaçôes ocorridas com o advento da economia-mundo industrial do século XIX impuseram aos senhores de escravos das Américas a necessidade do aumento constante da produtividade de seus cativos, sob o risco de se verem excluídos do mercado mundial. As forças entáo colocadas em jogo levaram, por um lado, ao colapso de antigas regióes produtoras no Caribe britânico e francês, que assim chegaram aos limites máximos de sua capacidade produtiva, e, por outro, à abertura de oportunidades para regiôes que até então haviam estado na periferia econômica das zonas de exploração escravista do Novo Mundo. Nesse movimento, os destinos de Cuba, do Brasil e do Sul dos Estados Unidos se entrelaçaram de modo estreito. Suas respectivas especializaçôes na produção em larga escala de açúcar, café e algodão remodelaram suas economias em um jogo de condicionamentos mútuos.

Em que pese toda a riqueza de tal mirada analítica, na formulação original da categoria Segunda Escravidão, Tomich não concedeu peso devido à dimensão do poder, isto é, à contribuição da política e da diplomacia no sistema interestatal do século XIX para a construção da nova estrutura histórica da escravidáo oitocentista. Acreditamos que o mapeamento desse quadro, explicitando a presença do cativeiro na orientação das relaçóes políticas entre Brasil, Espanha e Estados Unidos, tornará mais inteligível a crise desse mesmo sistema no período subseqüente ao grande conflito norte-americano. Pretendemos aferir, portanto, não os efeitos da Guerra Civil em outros países, mas as estruturas e articulaçôes institucionais que criaram a condição de existência desses mesmos efeitos.

Em uma primeira mirada, pode parecer improdutivo estabelecer paralelos entre as organizaçóes políticas dos Estados Unidos, do Brasil e de Cuba entre as décadas de 1820 e 1850, que pouco ou nada tiveram em comum. Afinal, o primeiro espaço, independente havia quatro décadas, destacou-se pelo arranjo federal - sempre aberto à incorporaçáo de novos estados à União como decorrência da expansão territorial da República - e por um sistema representativo que, além de permitir a presença simultânea no Congresso de partidos políticos nacionais dotados de relativo conteúdo programático, caminhou progressivamente para uma democracia construída sobre critérios raciais. O segundo espaço, uma monarquia centralizada independente apenas em 1822, lutou no período em tela contra os riscos de fragmentação territorial e montou um regime representativo que enfrentava, entre outros, os desafios de promover o rodízio de poder entre os partidos políticos, bem como o de administrar o exercício da cidadania política de negros e mulatos livres sem o desgaste de suas instituiçóes. E o terceiro espaço simplesmente não era nem se tornou independente durante o mesmo período, ao contrário de todos os territórios continentais da América.

Como é possível, então, tomar as tessituras políticas das três regióes em um enquadramento conjunto? Para além de estarmos tratando de um período - o século XIX - sobejamente marcado pelo problema da montagem do Estado nacional no contexto do sistema interestatal, acreditamos que dois pontos fulcrais unificaram a trajetória política desses três espaços: primeiro, o peso decisivo da escravidão negra em cada uma de suas ordenaçôes políticas; segundo, o modo pelo qual a emergência do movimento antiescravista internacional - transformado em arma geopolítica pela Grã-Bretanha condicionou os caminhos por eles seguidos.

Para demonstrar esses pontos, o artigo será dividido em três partes. Na primeira, apresentamos as respostas políticas locais nos Estados Unidos, no Brasil e em Cuba à emergência da internacional antiescravista capitaneada pela Grã-Bretanha (décadas de 1820 e 1830), que impôs novos desafios mundiais ao apertar o frouxo regime de consultas internacionais do sistema westfaliano ${ }^{6}$. Na segunda parte, 
tratamos dos esforços de construção de uma internacional escravista, cujo objetivo era unificar as classes senhoriais sulistas, brasileiras e hispano-cubanas frente ao desafio colocado pela aliança transatlântica entre abolicionistas britânicos e nortistas (década de 1840). Na seção final, analisamos os limites à consecução plena dessa internacional escravista, relacionados de modo direto à crise da estrutura histórica da Segunda Escravidão.

\section{Grã-Bretanha, internacional antiescravista e sistemas políticos nacionais}

Na virada para o século XIX, as interações políticas entre Estados Unidos, Brasil e Cuba pareciam "mornas", diante da intensidade que viriam a adquirir no futuro. Sem desprezar influências ideológicas, pode-se dizer que os fatores que os aproximavam remetiam, antes de tudo, à economia mundial, como a abertura de novos mercados consumidores (os próprios EUA, a partir da década de 1780), a elasticidade da demanda por artigos tropicais no Velho Mundo e o colapso de Saint-Domingue. Seu estreitamento político começou a acelerar-se apenas sob o impacto decisivo das estratégias napoleônicas concebidas entre 1802 e 1807. Com o fiasco do exército de Leclerc em Saint-Domingue (1802) e o fim do sonho de um império escravista francês no golfo do México, os Estados Unidos, impulsionados pelo medo da fronteira com súditos franceses veteranos da rebelião caribenha e pelo crescimento econômico de Kentucky e Tennessee (elevados a estados, respectivamente, em 1792 e 1796), que escoavam seus produtos pelo Mississipi, adquiriram o território da Louisiana (1803), convertendo-se numa potência imperial ${ }^{7}$. Não foram pequenos os efeitos políticos dessa transformação. Seus arquitetos, os republicanos da Virgínia, concentraram poder a ponto de esmagar as posiçóes federalistas no país, estimulando a crença de que a República se curvava demais aos desígnios dos senhores de escravos. Economicamente, a Louisiana abriu vastas terras ao cultivo do algodão, permitindo a montagem de um comércio negreiro interestadual que se valeria da reprodução vegetativa dos escravos.

Sem um império escravista próprio no Atlântico, a França adotou uma contra-ofensiva, no fim do período 1802-1807, que consistiu no Bloqueio Continental e na invasão da península ibérica - uma forma indireta de reobter controle sobre domínios americanos. Esses eventos acabaram por dar às três regiốes escravistas um novo protagonismo na arena mundial. A conquista ibérica por Napoleão (1807), ao estimular a independência da maior parte das entáo colônias hispânicas, permitiu que o senhoriato cubano, reforçando sua fidelidade à metrópole e permanecendo como um de seus únicos esteios materiais, ganhasse projeção política dentro da estrutura do império espanhol. Assim também aconteceria com o Brasil, para onde fugira a Coroa bragantina, acossada por Napoleão. A colônia, sendo colocada em primeiro plano nos cálculos de reabilitação econômica do império português, foi eleita sua sede temporária (1808) e definitiva (1815). Por fim, o Bloqueio Continental, que induziu a Grã-Bretanha a prender embarcações norte-americanas engajadas no comércio com a França, suscitou, indiretamente, a Guerra Anglo-Americana de 1812 - durante a qual o Sul, belicoso, ganharia notória ascendência sobre um relutante Norte.

Se as campanhas napoleônicas contribuíram para elevar essas três regióes escravistas ao centro de decisões de seus respectivos Estados, dando-lhes um novo protagonismo, não deixaram de suscitar desafios internos e externos aos arranjos políticos que pareciam beneficiá-las. As soluçóes a esses desafios, encontradas ao longo da década de 1820 e de 1830, foram formuladas dentro das respectivas estruturas nacionais dos Estados Unidos, Brasil e Cuba. Quando despontou a experiência abolicionista dos anos 1830, inspirada por pretensóes universalistas, novos encaminhamentos passaram a ser ensaiados, desta vez em nível internacional. Vejamos caso a caso.

No contexto do Bloqueio Continental, as abordagens unilaterais de navios norte-americanos por vasos de guerra britânicos produziram um jogo de retaliaçôes (embargos comerciais dos EUA à Inglaterra, a partir de 1808, e a subseqüente declaração de guerra, em 1812), que instalou a retórica 
antiescravista no centro das relaçóes entre os dois países e estabeleceu um precedente importante para a recusa norte-americana em colaborar na luta contra o tráfico transatlântico de escravos, vista como manifestaçáo imperialista britânica ${ }^{8}$. Durante o conflito, o desenvolvimento de um sentimento antiescravista nos estados do Norte, em gestação desde a compra da Louisiana, reduziu a heterogeneidade política dos EUA (Leste vs. Oeste; estados pequenos vs. Grandes; interesses mercantis vs. agrários) ao cada vez mais definido eixo Norte vs. Sul. Não à toa, as criações de estados após a aquisição da Louisiana (1812) tiveram de obedecer à regra de ouro do equilíbrio bilateral, resultando sempre em admissóes simultâneas de unidades com e sem escravos, como Mississipi e Indiana (1817), ou Alabama e Illinois (1819). Essa evoluçáo acabou eclodindo numa acirrada disputa sobre a incorporaçáo do Missouri como estado escravista, a chamada Crise do Missouri (1819-21), o mais sério conflito seccional ocorrido antes de 1850. A radicalização das posiçôes anti e pró-escravista no Congresso Federal exigiu, para se impedir o risco de quebra da União, a composição de um ajuste formal entre os representantes dos estados do Sul e do Norte sobre a extensão futura do cativeiro pelos territórios dos Estados Unidos`. O compromisso do Missouri alteraria profundamente a percepção norte-americana sobre sua sociedade e seu governo, tornando mais claras a caracterização da escravidão como um divisor geográfico, moral, político e econômico e a identificação do primeiro Partido Republicano com os interesses ao sul da linha Mason-Dixon.

Ao compromisso de 1820 devemos somar o aparecimento do Segundo Sistema Partidário (18281856) como parte do pacote que permitiu esvaziar as tensóes relativas à escravidáo negra que haviam aflorado na crise do Missouri. Como escreve David Brion Davis, o resultado do conflito "contribuiu para a criação de um sistema bipartidário nacional concebido para conter e neutralizar o tipo de discórdia regional que irrompeu em $1819{ }^{\prime \prime}$. De fato, durante a vigência desse sistema, democratas e whigs, organizados em escala nacional, evitaram a todo custo transformar a escravidão em questão política no plano federal. Alguns historiadores argumentam que o equilíbrio entre os dois partidos garantiu o exercício de um poder hegemônico dos senhores de escravos do Sul sobre a República antebellum ${ }^{11}$. A hipótese ganha validade se lembrarmos que vozes escravistas críticas ao Segundo Sistema Partidário, como as dos nulificadores da Carolina do Sul, exigiram anuências constantes dos líderes democratas e whigs à preservação da escravidão, com vistas à neutralização dos abolicionistas radicais do Norte.

Nesse ponto, entende-se como a atuação da Grã-Bretanha ajudou a configurar tal quadro político. Tendo sido decisiva ao colocar o problema da escravidão no centro das relaçóes anglo-americanas durante a Guerra de 1812, contribuindo, indiretamente, para a Crise do Missouri, a Grã-Bretanha intensificou seu papel de protagonista mundial do antiescravismo na década de 1830. A radicalização do movimento antiescravista britânico (com a passagem da plataforma de libertação gradual para a da emancipação imediata), a abolição da escravidão nas West Indies (com o início do processo de aprendizagem aprovado em agosto de 1833) e a fundação da Sociedade Americana Antiescravista em dezembro de 1833 geraram duras reaçóes dentro dos Estados Unidos. Cristalizando-se em fins da década de 1830 com o estabelecimento de uma aliança política formal entre abolicionistas norteamericanos e britânicos, esse feixe de forças antiescravistas intensificou, na década de 1840, o poder do bloco escravista na União. O papel de vanguarda nesse bloco coube à Carolina do Sul, ainda que seus principais líderes políticos se afastassem das linhas mestras da democracia jacksoniana ${ }^{12}$. A GrãBretanha chegaria a ser considerada a "inimiga natural" da República norte-americana durante praticamente todo o período antebellum ${ }^{13}$.

Os atores políticos no Brasil e em Cuba responderam de outra maneira às transformaçôes que a escravidão sofreu no mundo atlântico. A abolição do tráfico transatlântico de escravos para as possessóes britânicas em 1807 deu ensejo, já no ano seguinte, a que a Grã-Bretanha pressionasse Portugal e Espanha para que adotassem medida semelhante em relação às suas colônias americanas. Diante das exigências das guerras napoleônicas, essa pressão não foi de grande vulto até 1815 . Com a volta da paz 
à Europa, o antiescravismo militante expresso no combate ao tráfico transatlântico de africanos tornouse peça essencial da diplomacia britânica. Nas cinco décadas seguintes, o alvo prioritário de sua atuação seriam justamente Portugal, Brasil independente e Espanha - leia-se Cuba. Em livro recente, exploramos exaustivamente as articulaçôes entre a política da escravidão no Brasil e em Cuba de 1790 a $1850^{14}$. Aqui, iremos destacar de forma breve dois momentos nas respostas políticas dadas à pressão britânica.

O primeiro é o da crise do sistema atlântico ibérico, isto é, a quadra compreendida entre a invasão napoleônica da Península Ibérica (1807) e o término das guerras de independência (1824). Nessa conjuntura, a atuação política das classes senhoriais do Brasil e de Cuba guiou-se por três objetivos bastante claros: garantir a continuidade do tráfico transatlântico de escravos e a livre conexão com o mercado mundial, mantendo-se simultaneamente a ordem social interna. Durante a primeira experiência constitucional de Cádiz (1810-1814), os senhores de escravos cubanos enfrentaram ameaças como a oposição dos liberais gaditanos ao princípio do livre comércio e, em particular, os planos para acabar com o tráfico e a escravidão, que impulsionaram, na ilha, conspiraçôes de escravos e homens livres de cor contra a ordem escravista. Com a primeira restauração de Fernando VII (1814-1820), por seu turno, os senhores cubanos se viram diante da possibilidade de obter ganhos políticos e econômicos efetivos por meio da negociação direta com o monarca, enquanto, no continente, a reação absolutista impulsionava o movimento de independência e a quebra da ordem escravista. A crise do sistema atlântico ibérico se manifestou de modo distinto no Brasil, dada a fuga da família real portuguesa para a América, mas seus resultados finais foram congruentes ao que se verificou em Cuba. Durante a década de 1810, o Brasil - elevado a Reino Unido a Portugal e Algarves, em 1815 - demonstrou a viabilidade de se manter o tráfico transatlântico de escravos a contrapelo da pressáo britânica, promover o livre comércio total e evitar as perturbaçôes revolucionárias envolvidas na quebra da ordem imperial. Em realidade, a política do Brasil joanino para a escravidão se converteu em modelo para as classes senhoriais cubanas negociarem sua posição dentro da monarquia espanhola, durante a reação absolutista de Fernando VII.

No segundo momento (1824-1837), a concentração dos poderes políticos e militares na figura do capitáo general, pelo decreto real de maio de 1825, deu às classes senhoriais de Cuba canais mais amplos para lidar com as ameaças embutidas em uma eventual guerra de independência, como o risco de revoltas escravas ou de interferência britânica. A medida havia sido adotada por Fernando VII - novamente capitaneando uma restauração absolutista na Espanha - em resposta às demandas dos grupos escravistas cubanos contrários à ampliação da esfera pública ocorrida durante as Cortes do Triênio Liberal (1820-1823). Com a volta do regime representativo na metrópole em 1836-37, o regime de faculdades onímodas dos capitães generais pôde ser perpetuado em Cuba graças à atuação de parte das classes senhoriais cubanas e da maioria dos deputados metropolitanos, contra outros grupos desejosos de substituí-lo por um texto constitucional que vigoraria na ilha. Assim, surgiu uma equação política peculiar, na qual grupos escravistas e anticonstitucionalistas da colônia se aliaram a políticos constitucionalistas da metrópole (alguns dos quais com sentimentos antiescravistas) para manter, a um só tempo, a unidade imperial, a escravidáo e o contrabando negreiro.

Esses dois grupos garantiram o convívio do governo representativo na Península com a exclusão da representação parlamentar colonial, com a inaplicação da Constituição espanhola no ultramar e com a conseqüente abolição das deputaçôes provinciais. Mas, se os princípios adotados em 1837 abriram espaço para um novo leque de tensôes, forneceram também as bases para a modernização e o crescimento da produção escravista de Cuba. Naquele momento, arrematou-se a construção do "Segundo Império Espanhol” (a expressão é de Christopher Schmidt-Nowara), um arranjo que respondeu diretamente à pressão antiescravista britânica, dando guarida à manutenção do tráfico negreiro transatlântico sob a forma do contrabando. Politicamente, o Segundo Império Espanhol pode ser caracterizado pela ausência de representação parlamentar para os súditos coloniais, pelo princípio da cidadania racializada e pela composição estatutariamente biaxial de "zonas constitucionais" (províncias da metrópole) e "zonas não- 
constitucionais" (territórios ultramarinos). A contrapartida mais notável desse pacto é que ele tornou a escravidão negra sua razão de ser, de forma que não foi difícil, aos grupos coloniais interessados no exercício político parlamentar, associar a instituição do cativeiro à limitação de seus próprios direitos. A revisão do pacto imperial, identificada, por exemplo, com o reformismo do grupo de José Antonio Saco, passou a pressupor o discurso antiescravista.

Após a década de 1820, o Império do Brasil apresentou trajetória sensivelmente distinta da de Cuba. Sua independência, em 1822, abrira grande flanco para a pressão britânica, pois, desde o Tratado AngloPortuguês de 1817, firmado pelo então rei de Portugal, a questão estivera congelada no plano diplomático. Em troca do reconhecimento formal do novo Estado soberano, a Grã-Bretanha exigiu do imperador do Brasil, D. Pedro I, compromisso efetivo com o encerramento do tráfico. A matéria se resolveu apenas em 1826, com a assinatura da convenção que previa o fim do tráfico entre África e Brasil para três anos após sua ratificação pela Grã-Bretanha, o que ocorreu em março de 1827. A arenga diplomática, além de erodir parte náo desprezível do capital político do primeiro imperador do Brasil e contribuir para sua queda em 1831, foi acompanhada de perto por negreiros e fazendeiros, que aceleraram as importaçóes de africanos na segunda metade da década de 1820, algo que expressava com nitidez a concepção coeva de que o tráfico seria efetivamente encerrado em 1830.

Com o objetivo de reafirmar a soberania brasileira na questão, um Parlamento bastante fortalecido com a queda de D. Pedro I aprovou a lei de 7 de novembro de 1831, que trazia disposiçóes draconianas para combater o tráfico: os africanos que doravante fossem introduzidos em território nacional seriam automaticamente libertados, prevendo-se seu retorno imediato à África; os transgressores - vendedores ou compradores - seriam submetidos a processo criminal; as denúncias contra a prática tanto do desembarque ilegal como da mera posse de escravos ilegais poderiam ser apresentadas por qualquer indivíduo. $\mathrm{Na}$ letra da lei, portanto, os fazendeiros que adquirissem africanos no trato transatlântico ficariam expostos a severas puniçóes. Usualmente reputado como "para inglês ver", o diploma de 7 de novembro pretendia de fato acabar com o tráfico transatlântico, e deste modo foi lido pelos coetâneos. Tanto é assim que, entre 1831 e 1834, os desembarques negreiros no Brasil desabaram para o menor nível desde fins do século XVII. O tráfico tornou-se como que residual.

Logo, no entanto, as grandes reformas do Ato Adicional (1834) e a abolição da escravidão no Caribe britânico redefiniram as disputas na política brasileira. De 1835 em diante, ocorreu uma reversão profunda no quadro acima descrito. As vozes pró-escravistas voltaram a se articular nos espaços de opiniáo pública após um período de refluxo, e uma ampla coalizão de ex-liberais moderados, expartidários de D. Pedro I e grandes proprietários de escravos do centro-sul do Brasil - a base social da formação do futuro Partido Conservador - passou a advogar pura e simplesmente a anulação da lei de 1831. Nesse movimento de mão-dupla entre as demandas da classe senhorial e os esforços de arregimentação de eleitores por parte de uma nova força política, os fazendeiros de café do Vale do Paraíba (a zona econômica mais dinâmica do Império do Brasil ao longo do século XIX) desempenharam papel fulcral, ao demandarem por meio de pressão política direta e de açóes no espaço público a reabertura do tráfico transatlântico. Tornando a matéria, desde 1835, pauta de campanha política, os agentes do Regresso Conservador (futuramente conhecidos pela alcunha de saquaremas) acenaram aos traficantes, cafeicultores e senhores de engenho que dariam sinal verde à retomada do infame comércio. A estratégia funcionou muito bem, pois, na segunda metade da década de 1830, enquanto desembarcavam nos portos do centro-sul quase 240.000 africanos ilegalmente escravizados, número que subiu para mais de 300.000 nos anos quarenta, os saquaremas conseguiram impor integralmente sua agenda à política imperial. $\mathrm{O}$ quadro institucional que os conservadores brasileiros erigiram entre as décadas de $1830 \mathrm{e}$ 1850 demonstraria ser tão sólido e duradouro quanto a estrutura biaxial do Segundo Império Espanhol e o Segundo Sistema Partidário norte-americano. 


\section{A internacional escravista}

Como se vê, o compromisso do Missouri, o regime de faculdades onímodas e a crise do Primeiro Reinado foram arranjos distintos desenvolvidos como respostas ao problema comum de como expandir o cativeiro numa conjuntura politicamente tensa. Nos três casos, as instituiçóes desenhadas colocaram o poder de decisão sobre o futuro do sistema escravista ao alcance dos proprietários, numa clara tentativa de se obter o que pode ser chamado de governabilidade da escravidão. Só que, é claro, as formas específicas desses arranjos acabaram sendo condicionadas pela cultura política, pela composiçáo social e pela estrutura de governo de cada região. Nos Estados Unidos tentou-se congelar a iniciativa do Congresso, visto como instância dividida por representar uma sociedade escravista (Sul) e uma sociedade não-escravista (Norte); em Cuba, concentraram-se os poderes nas mãos de uma figura militar radicada no seio do senhoriato local e, portanto, sujeita a sua constante influência; no Brasil, o poder decisório foi deslocado de um Executivo inicialmente fortalecido pela Carta de 1824 para o Legislativo, percebido como instância representativa dos interesses de uma sociedade plenamente escravista.

Até os anos 1830, portanto, esses espaços criaram marcos legais e amplos acordos domésticos para enfrentar os desafios associados a impasses locais e ao sistema interestatal regulado pela Grã-Bretanha. Cada país mirou, sem dúvida, os eventos ocorridos nos outros lugares e incorporou as experiências anteriores num processo de aprendizagem cumulativa, mas não há evidências explícitas de apoio entre eles no plano internacional. A partir da década de 1830, em contrapartida, vemos não só a evolução dos acordos domésticos para os arranjos do Segundo Sistema Partidário norte-americano, do Segundo Império Espanhol e do sistema bipartidário brasileiro sob hegemonia saquarema, mas também as respectivas articulaçóes desses arranjos com a evolução do antiescravismo internacionalista capitaneado pela Grã-Bretanha. Mais do que um jogo de imitação, os atores históricos das regióes escravistas americanas passaram a vislumbrar também a construção de açóes coordenadas contra um inimigo comum. A emulação perderia espaço para a cooperação.

A primeira evidência da nova conjuntura é a substituição dos impérios britânico e francês pela República dos Estados Unidos como modelo de decisóes governativas. Em 17 de julho de 1839, por exemplo, durante ácido debate na Câmara dos Deputados do Império do Brasil sobre a conivência de altas autoridades saquaremas com a retomada em grande volume do tráfico ilegal, Honório Hermeto Carneiro Leão - um dos líderes do regresso conservador então em curso e ele próprio cafeicultor no Vale do Paraíba - lembrou a perseguição sofrida pelos abolicionistas nos Estados Unidos, sugerindo que conduta semelhante fosse aplicada, no Brasil, àqueles que se pronunciassem publicamente contra a escravidáo. A experiência abolicionista, noutros termos, devia ser vista por lentes norte-americanas, e não britânicas. "Crescendo em 1835 e 1836 naquele país a sanha dos abolicionistas", disse ele no Parlamento em referência às dezenas de motins populares eclodidos contra a atuação da Sociedade Americana Antiescravista, "os estados onde há escravos se lhe opuseram, e o povo dos estados onde não há escravatura entendeu, julgando ameaçados os interesses dos estados em que havia escravos, não dever ser mero espectador, mas dever tomar a iniciativa para punir os abolicionistas" ${ }^{15}$. Embora as circunstâncias locais dos levantes antiabolicionistas nas unidades federativas do Norte, marcadas pelo desejo de enrijecer as divisóes raciais entre negros e brancos livres, fossem distintas das encontradas no Brasil, onde as barreiras raciais eram mais fluidas, a fala de Carneiro Leão (futuro marquês do Paraná) visava expor, aos grupos locais contrários à reabertura do tráfico transatlântico, que os agentes próescravistas do Império do Brasil não estavam sozinhos na arena mundial.

Gradualmente, os Estados Unidos não se tornaram apenas a referência central para as demais potências escravistas, mas também induziram a formação de uma ação convergente com Cuba e Brasil. Explorar todas as relaçôes entre as forças globais e os processos políticos nacionais nessa matéria constitui, em si, uma vasta agenda de pesquisa. Por ora, cabe apenas expor rapidamente os esforços 
envidados para a construção de uma internacional escravista, em algumas ocasióes críticas, depois que a Grã-Bretanha elevou a intensidade de sua campanha global contra o tráfico transatlântico de escravos e a escravidão negra.

A primeira delas foi quando o movimento antiescravista britânico e o norte-americano formalizaram uma aliança transatlântica. A experiência do "sistema de aprendizagem" foi acompanhada de perto nos Estados Unidos por abolicionistas e pró-escravistas. Com a emancipação definitiva, em 1838, e a formação de uma nova sociedade antiescravista na Grä-Bretanha (a British and Foreign Anti-Slavery Society, que já em seu nome expressava a plataforma internacionalista), em 1839, concretizaram-se os laços entre os abolicionistas dos dois lados do Atlântico. Reunidos em Londres, em 1840, os participantes da primeira World Anti-Slavery Convention subscreveram integralmente a política militar e diplomática agressiva de Lord Palmerston contra o tráfico transatlântico para o Brasil e Cuba, defenderam a aplicação do princípio do solo livre como instrumento de pressão contra o tráfico interno de escravos nos Estados Unidos e posicionaram-se pela abolição da escravidão no Texas em troca de um eventual reconhecimento de sua independência pela Grã-Bretanha. Além dos abolicionistas, o governo britânico também sofreu a pressão de duas forças sociais opostas. De um lado, os trabalhadores ingleses vinham reivindicando melhores condiçóes de vida, inclusive o acesso livre a artigos coloniais, que, então sob monopólio antilhano, sofriam alta de preço em virtude da quebra sentida desde o fim da aprendizagem (1838). O lobby antilhano, de outro lado, pressionava a Coroa por açôes enérgicas contra Brasil e Cuba, seus concorrentes diretos que, numa situação de livre mercado, teriam ampla vantagem competitiva por causa do acesso ilimitado aos africanos escravizados ${ }^{16}$.

Sob o acicate desses três grupos sociais (abolicionistas, trabalhadores e proprietários caribenhos), a Grã-Bretanha adotou um novo padrão diplomático que resultou na assinatura do Tratado de Londres, em dezembro de 1841, arrastando França, Rússia, Prússia e Áustria à doutrina do direito de busca e na tentativa de inserir uma cláusula de emancipação escrava na confecção de um novo tratado de comércio com o Brasil em substituiçáo ao de 1810 (refeito em 1826 e que valeria até 1842-44) ${ }^{17}$. Ao mesmo tempo, o Foreign Office sugeriu uma série de medidas para suprir a carência de trabalhadores nas colônias, como a proposta feita aos Estados Unidos em 1842 para a emigração de negros livres do país às Antilhas, ou o simples confisco de africanos ilegalmente destinados a Cuba ou ao Brasil. Nessa época, a atuação de agitadores abolicionistas britânicos em Cuba (no famoso affaire Madden-Turnbull) e a convocação de uma segunda convenção antiescravista mundial, a realizar-se em 1843, indicaram aos interesses senhoriais que estava em marcha uma ampla conspiração visando a acabar com a escravidão nos Estados Unidos, no Brasil e em Cuba. Noutros termos, reconhecendo o fiasco econômico da abolição de 1833, parecia que a Grã-Bretanha, por motivos materiais, e não apenas humanitários, avançava contra seus concorrentes diretos ${ }^{18}$.

Os historiadores Gerald Horne e Edward Rugemer examinaram os esforços promovidos por agentes do executivo norte-americano durante a administração John Tyler (1841-1845) para construir uma frente única com Brasil e Espanha/Cuba a fim de enfrentar as ações antiescravistas da Grã-Bretanha ${ }^{19}$. Dessa forma, mais do que arrolar todas as iniciativas diplomáticas do triunvirato pró-escravista representado pelo jornalista-diplomata Duff Green, pelo Secretário de Estado Abel Upshur e, sobretudo, pelo líder sulista John C. Calhoun, vale destacar a receptividade em Cuba e no Brasil a algumas de suas açóes de repercussão internacional.

O primeiro evento indicativo da nova configuração de forças no quadro mundial ocorreu em 1840 . Alguns anos antes, navios norte-americanos que transportavam escravos de Virginia e Maryland aos estados do Golfo do México acabaram perdendo sua mercadoria quando, avariados por intempéries, arribaram nas colônias britânicas, onde o princípio jurídico do solo livre vinha sendo adotado desde a abolição de 1833. Como as ferrovias planejadas para ligar a costa atlântica do Sul ao interior náo saíram do papel nos anos 1830 (principalmente depois do pânico financeiro de 1837), a rota intercostal con- 
tinuava sendo o único meio de transporte capaz de alimentar o boom algodoeiro, devendo, assim, ser protegida de confiscos que criavam insegurança jurídica no comércio e majoravam o preço dos seguros, numa conjuntura de queda internacional dos preços do algodáo. Para tanto, John Calhoun fez passar uma moção de protesto no Senado, em caráter de unanimidade, reafirmando que, para o Congresso, não havia diferença "entre este [propriedade escrava] e qualquer outro tipo de propriedade". Desta feita, seria oportuno repudiar a libertação dos escravos americanos como violação do direito internacional e, portanto, como ato passível de retaliaçáo em caso de reincidência. Ao pedir aprovaçáo unânime na Casa, Calhoun sabia que estava produzindo um documento para mostrar à comunidade internacional o pleno consenso dos Estados Unidos a respeito de suas instituiçóes domésticas ${ }^{20}$.

Não foi então mera eventualidade que, aprovada por 33-0 (com quinze abstençôes, de antiescravistas), a moção repercutisse de imediato em Cuba. Desde 1840, o governo espanhol vinha lidando com a escalada da diplomacia britânica, que passara a exigir a emancipação dos escravos ilegalmente introduzidos nas colônias antilhanas após 1820 , primeiro ano da vigência do tratado anglo-espanhol contra o tráfico negreiro. Uma de suas respostas a essa pressão consistiu na promessa de supressão do tráfico negreiro e na redação de um código legal destinado a regular a relaçáo entre senhores e escravos, a fim de garantir a reprodução vegetativa dos cativos. Quando o capitão general de Cuba, Gerónimo Valdés, distribuiu um questionário sobre a matéria entre doze fazendeiros em 1842, um dos mais proeminentes, Wenceslao de Villa Urrutia, náo hesitou em incorporar o recente lance de Calhoun nos Estados Unidos para barrar a proposta:

O Senado dos Estados Unidos acaba de inserir deliberadamente em uma de suas atas relativa a servos de cidadáos americanos a palavra escravos, inusitada em sua Constituição e em todos os documentos da legislaçấo e do governo federal, com o único objetivo de fazer entender à nação poderosa que se ocupa em minar e destruir a escravidão em certos países que o Congresso dos Estados Unidos a considera uma instituição legal com todas as suas conseqüências e que está pronto a sustentá-la e defendê-la contra todo gênero de ataques. Ação oportuna e exemplar de dignidade nacional que nem um voto abolicionista ousou contradizer! Os verdadeiros espanhóis não cedem a ninguém na posse dessas qualidades, e Cuba espera que o governo pertença a esse número. ${ }^{21}$

Os anos 1841-45 tampouco foram fáceis para o Brasil. O período foi marcado por uma tensa renegociação do tratado comercial anglo-brasileiro, que tinha validade até 1842 e acabaria sendo estendido até 1844. A insistência da Grã-Bretanha em inserir uma cláusula de emancipação futura dos escravos em troca de concessóes tarifárias ao açúcar brasileiro, concorrente direto do caribenho, caiu feito uma bomba no Parlamento. Um deputado sensível aos espaços antisistêmicos que a própria hegemonia britânica criava, contextualizou a posição do Brasil no sistema interestatal da época sugerindo que o país, não estando só, podia manter-se irredutível na renegociação sem o risco de represálias: "Os ingleses armaram-se contra os chineses e os venceram; mas há de suceder o mesmo no Brasil? Consentirão os Estados Unidos e a França nesse bloqueio?"22. Paralelamente, personagens saquaremas como Bernardo Pereira de Vasconcelos e João Manoel Pereira da Silva empregaram em discursos, esgrimidos no Parlamento ou publicados na imprensa da Corte, os mesmos argumentos pró-escravistas que vinham sendo ventilados por Green, Upshur, Calhoun e demais asseclas. O fracasso da experiência da emancipação no Caribe britânico, o colapso econômico das repúblicas da antiga América espanhola que haviam abolido a escravidão, a perfídia e a hipocrisia britânicas reveladas pelas suas açóes na Irlanda e na Índia foram tópicas mobilizadas com os mesmos propósitos no Sul dos Estados Unidos e no Império do Brasil ${ }^{23}$.

Há, na correspondência diplomática brasileira emanada de Londres no ano de 1843, indícios consistentes sobre a existência de uma correia de transmissão direta entre as gestóes de Green-Upshur-Calhoun pela anexação do Texas como meio de enfrentamento da Grã-Bretanha e os projetos saquaremas de manutenção do tráfico negreiro transatlântico ilegal. $\mathrm{O}$ agente brasileiro incumbido de renegociar o tratado 
comercial sem aceder à proposta de emancipação mencionou o encontro com um jornalista aliado de Calhoun e Hammond, enviado em caráter não-oficial a Londres. Embora não desse seu nome, as alusóes credenciam o informante oculto como Duff Green. Segundo o brasileiro, Green

me procurou como antigo conhecido, e, por suas conversaçóes, fui informado de que também tinha vindo com a incumbência de falar acerca da emancipação dos escravos com as pessoas influentes com quem tratasse. O procedimento do governo inglês em querer seduzir o Brasil e Cuba a emancipar seus escravos, disseme ele que inquietava em demasia ao governo Americano, o qual considerava esse procedimento como uma intervenção ilícita que se arrogava a Inglaterra nos negócios internos de outros povos. Disse-me também que, para evitar os efeitos dessa intervençáo no território de Texas, se dispunha o Presidente dos Estados Unidos a propor ao Congresso a incorporação dessa República. ${ }^{24}$

Em 1844, o argumento do controle nacional da instituição também pautou as instruçóes diplomáticas que Calhoun enviou ao representante norte-americano radicado no Império do Brasil, justificando a decisão de anexar o Texas. Em sua missiva, disse que "Nossa política é não interferir em questôes internas de outras nações e não permitir também que outras naçôes o façam conosco". Depois, completou: "É do mais profundo interesse para o Brasil adotar essa mesma fórmula política", pois "a política da Grã-Bretanha é destruir estas relaçóes [entre escravos e senhores] nos dois países e no mundo inteiro. [...] Destruir a escravidão, em qualquer das duas naçóes, facilitaria a destruição (da mesma instituição) na outra" ${ }^{25}$. As falas dos norte-americanos foram incorporadas rapidamente por políticos brasileiros. Numa sessão do Senado de 3 de julho de 1845, Carneiro Leão manifestou de modo cristalino como os Estados Unidos forneciam um modelo ao Brasil de enfrentamento das vozes antiescravistas e de defesa positiva da escravidão:

um dos elementos da existência da sociedade brasileira é a escravatura; este elemento não poderá ser destruído sem a destruição e dano da mesma sociedade. Não se deve tolerar [...] falar contra uma instituição da sociedade brasileira que tem de o ser por muitos séculos, porque se deve esperar que esta sociedade seja governada por brasileiros, cujos interesses permanentes e reais têm de exigir por muitos séculos a conservação da escravidão. ${ }^{26}$

Coincidindo com esse realinhamento ideológico da ordem mundial, uma jogada da diplomacia norte-americana pode ter insuflado a ousada recusa brasileira em fechar um acordo com a Grã-Bretanha na antevéspera da expiração do tratado antitráfico de 1826 (ratificado em 1827 e previsto para durar até 1845). No começo dos anos quarenta, os brasileiros conheciam de perto a experiência de Portugal, que, após o choque súbito do bill Palmerston (1839), tratara de aviar uma receita pacífica para a crise, assinando um tratado bilateral em $1842^{27}$. Na prática, o ajuste tirou de combate a bandeira do país para a realizaçáo do contrabando negreiro. Do ponto de vista brasileiro, essa derrota vinha sendo largamente compensada por uma vitória adquirida, justamente no mesmo ano de 1842, com a assinatura do tratado anglo-americano de Ashburton-Webster. Ao contrário do anglo-lusitano, esse tratado impedia que vasos ingleses abordassem navios comerciais norte-americanos - isto é, não se concedia o direito de busca. $\mathrm{O}$ início da década mostrava, portanto, que, se a antiga metrópole portuguesa era incapaz de enfrentar abertamente a Grã-Bretanha, os Estados Unidos se apresentavam como a única potência apta a fazê-lo. Ignorar sobranceiramente a "pérfida Albion", como fez o Império em 1845, ao rejeitar a renovação do tratado antitráfico, não punha em risco o corredor legal aberto por Ashburton-Webster e ainda passava por um gesto de reafirmaçáo da soberania nacional.

Não é de admirar, portanto, que os capitais, os navios e, acima de tudo, a bandeira norte-americana tenham adquirido importância crescente no tráfico ilegal de escravos para o Brasil ao longo da década de $1840^{28}$. Diante dessa reconfiguração e ciente de que as trocas comerciais - ao contrário do credo liberal - não prescindiam do Estado, a Grã-Bretanha entendeu atacar o centro do poder imperial brasileiro por meio da pressão naval direta - sob as provisões do Bill Aberdeen - e de uma políti- 
ca de isolamento internacional do Brasil. Tornaram-se claras então as fragilidades de uma eventual aliança entre os saquaremas e o campo pró-escravista norte-americano. Se, por um lado, a bandeira norte-americana podia servir de abrigo aos negreiros que operavam no Atlântico Sul, muito em razão do arraigado sentimento antibritânico nos Estados Unidos (cujo viés era indiscutivelmente próescravista), por outro lado a República não tinha como amparar formalmente, na arena diplomática mundial, o tráfico ilegal para o Brasil.

No caso de Cuba, a estratégia que a Grã-Bretanha adotou com o Império sul-americano era irrealizável. Temos, aqui, a outra face da internacional escravista. Desde a presidência de Thomas Jefferson, vinham circulando nas altas esferas do poder federal norte-americano projetos para anexar a colônia espanhola à União. Nos anos vinte, esses planos encontraram alguma ressonância em Cuba, mas foi na conjuntura crítica de 1839-1843, quando as classes senhoriais cubanas se viram acuadas pela ação abolicionista britânica e pelos setores racialmente subalternos da ilha (escravos e homens livres de cor), que o anexionismo adquiriu vigor. A equação parecia ser simples aos senhores hispano-cubanos: se a Espanha não demonstrasse ser capaz de frear os riscos de uma aliança entre abolicionistas britânicos e africanos e afro-descendentes em Cuba, não lhes restaria outro caminho que a aliança com o maior poder escravista do continente ${ }^{29}$.

O anexionismo como movimento político arrefeceu após a Conspiração de La Escalera (18431844), para voltar com força no exato momento em que a Grã-Bretanha lançava seu ataque decisivo contra o tráfico transatlântico de escravos para o Brasil (1848-1851). O impulso norte-americano em direção ao Texas, bem como ao Novo México e à Califórnia, se materializou no curso bem-sucedido da guerra contra o México, deflagrada em 1846 para assegurar a posse dos cobiçados territórios, e acabou por fornecer um exemplo concreto de força militar e habilidade política que reanimou a esperança de anexionistas em Cuba e nos Estados Unidos.

São, assim, compreensíveis as diferenças de tratamento que a Grã-Bretanha dispensou a Cuba e ao Brasil na repressão ao comércio negreiro. Em 1852, lorde Stanley explicou ao chefe do Foreign Office britânico, lord Malmesbury, as razóes delas: "a opção de emitir, no caso de Cuba, ordens semelhantes àquelas que foram dadas por Palmerston e recuperadas por nós no caso do Brasil equivale, quase, a uma declaração de guerra". Sobreviria, como inevitável conseqüência, a anexação da ilha pelos Estados Unidos. A formulação de lorde Stanley mostra como a inserção de Cuba no jogo geopolítico do Atlântico norte era um poderoso freio ao fim do contrabando: em seus termos, "Se você estabelece um bloqueio ou qualquer coisa parecida, excitará nos Estados Unidos uma gritaria de 'interferência britânica’ e, imediatamente, vão acreditar que você está prestes a tomar Cuba" ${ }^{30}$. Fundamentais para criar esse campo de forças que neutralizava as investidas britânicas, mantendo Cuba na órbita espanhola a contrapelo do anexionismo, foram os grupos escravistas da ilha e dos Estados Unidos: enquanto uns flertavam com a anexação se a metrópole cedesse à Grã-Bretanha, outros prometiam incorporar a colônia vizinha se a Grã-Bretanha pressionasse a Espanha. Como se vê, embora cada qual tivesse um interlocutor imediato - os cubanos, a Espanha; os americanos, a Grã-Bretanha -, sua união acabou sendo decisiva para proteger por meios indiretos a continuidade do tráfico transatlântico ilegal para a ilha.

Algo semelhante pode ser vislumbrado no Império do Brasil, cujo trânsito interprovincial de escravos articulou-se rapidamente após o fechamento do tráfico transatlântico ilegal. Embora existisse antes de 1850, foi apenas depois dessa data que o tráfico interno de escravos se desenvolveu a olhos vistos, em uma escala equiparável em termos relativos ao comércio congênere no Sul dos Estados Unidos ${ }^{31}$. Já em 1851, ocorreu um episódio crucial para a estabilidade institucional do novo ramo negreiro. Naquele ano, um cruzeiro britânico aprisionou o navio Piratinim na costa brasileira, engajado não no comércio negreiro transatlântico, mas no tráfico da Bahia para São Paulo. Seus mais de cem escravos acabariam libertados e conduzidos às Antilhas britânicas, o que gerou grandes temores quanto às repercussóes do caso sobre a economia e a ordem social no Império do Brasil. No auge da crise, Paulino José Soares de 
Sousa, então ministro dos Estrangeiros, cogitou entregar a navegação de cabotagem brasileira à bandeira dos Estados Unidos. A ameaça não era fortuita: o representante brasileiro evidentemente tinha em vista não só a prática corrente do contrabando pelo Atlântico, como também os casos do Enterprise e do Creole, que resultaram no enfrentamento norte-americano com a Grã-Bretanha em torno do tráfico interno na via Upper South-Estreito da Flórida-Golfo do México. O gesto de Paulino Soares, somado à repressão do tráfico transatlântico ilegal, fez o Foreign Office retroceder ${ }^{32}$.

O Sul dos Estados Unidos converteu-se, na primeira metade da década de 1850, em modelo demográfico e político aos que, como os saquaremas, enxergavam na permanência da escravidão negra a condição para inscrever o Brasil na modernidade. Discursos na imprensa e no Parlamento lembravam o sucesso norte-americano em ampliar sua população escrava sem o concurso do tráfico transatlântico, valendo-se de medidas de aprimoramento da gestão da força de trabalho escravizada ${ }^{33}$. No Conselho de Estado do Império do Brasil, os estadistas elogiaram o chamado Compromisso de 1850, costurado nos Estados Unidos depois que a agitada aceitação da Califórnia como estado livre foi atenuada com medidas pró-Sul, entre as quais uma lei mais dura de devolução de escravos fugitivos e a delineação de uma fronteira ocidental mais segura para o Texas. Nas palavras do principal parecerista, marquês de Olinda, senhor de engenho em Pernambuco, que tinha em vista fulminar um projeto de emancipaçáo gradual apresentado ao governo,

aí está esse povo que habita o norte do nosso continente, o qual ainda não se atreveu a alterar a sua legislação sobre a escravidão, e que nos está dando o testemunho mais autêntico da condescendência que o legislador deve guardar para com as idéias e os interesses dos governados; e isto apesar dos esforços de um partido imenso e bem constituído, que solicita essas reformas, e de estas serem altamente aplaudidas por uma grande e numerosa parte da nação. ${ }^{34}$

Contudo, ao contrário do que previra Olinda no Conselho de Estado brasileiro, o Compromisso de 1850 não freou a crescente seccionalização da política interna norte-americana. Apenas um ano depois de seu parecer, o senador de Illinois Stephen Douglas propôs a suspensão do Compromisso do Missouri (isto é, da predeterminação do regime de trabalho segundo o paralelo $36^{\prime} 40^{\circ}$ ), repassando aos colonos locais a escolha do sistema a ser adotado nas novas unidades federativas adquiridas no Oeste. A tática, que pretendia esvaziar a pressão abolicionista sobre o Congresso e estimular o povoamento de novas áreas prestes a ser especuladas durante a construção de uma nova ferrovia Leste-Oeste, acabou por estimular a composição do segundo Partido Republicano e a conseqüente escalada das tensóes que em pouco tempo conduziriam à eclosão da Guerra Civil ${ }^{35}$.

Não contribuiu menos a radicalização do pró-escravismo militante sulista, cuja dimensão internacionalista se tornou ainda mais acentuada em meados do século. Suas duas expressóes máximas, embora não necessariamente convergentes, relacionaram-se com Cuba e Brasil: de um lado, radicais sulistas recrudesceram o movimento de anexação de Cuba; de outro, tentaram reabrir o tráfico transatlântico de escravos. Na década de 1850, em especial após 1854 (aprovação do Ato Kansas-Nebraska), a anexaçáo de Cuba se tornou matéria seccional, concebida nos estados do Sul como meio de contrabalançar o crescente poder antiescravista nos estados do Norte. Fosse por via flibusteira ou por compra, anexar Cuba significaria aumentar o peso do Sul na União ou, então, lançar as bases para a montagem de um império escravista autônomo na zona circum-caribenha. As movimentaçóes de 1854-1855 produziram profundo desconforto na Espanha, em especial depois da publicidade em torno do Ostend Manifesto, composto em outubro de 1854. Esse documento infame, que prefigurava uma guerra por Cuba, caso a Espanha se recusasse a vender a ilha aos Estados Unidos, serviria também como arma de propaganda para o recém-formado Partido Republicano denunciar às audiências do Norte o avanço da Slave Power Conspiracy - ou seja, o fato de os senhores de escravos estarem a ponto de reinstitutir a escravidão em todos os estados da República. Quando, em 1859, o presidente Buchaman tentou 
recolocar em pauta a compra de Cuba, o projeto foi derrubado tanto pela rejeição cabal da Espanha (que contava com respaldo britânico) como pela oposição ferrenha dos republicanos ${ }^{36}$.

Quanto ao movimento pela reabertura do tráfico transatlântico, ele derivou tanto da demanda acentuada por escravos nos estados do Deep South, em resposta à febre algodoeira e à revolução dos transportes terrestres nos anos 1850, como da plataforma radicalizada dos fire-eaters, que viam na medida um meio de afrontar abertamente os opositores da escravidão e, assim, impulsionar o movimento pela secessão ${ }^{37}$. Em alguns dos discursos que esposaram a causa no Sul, a expansão acelerada do sistema escravista valeria não apenas aos Estados Unidos, mas também ao Brasil, concebido como potencial fronteira agrícola para os senhores de escravos sulistas. Essa aproximação foi facilitada pela nomeação consecutiva de dois sulistas, William Trousdale (Tennessee) e Richard Meadde (Virgínia), como diplomatas no Brasil para o longo período de 1853 a 1861. No Correio Mercantil, o futuramente célebre romancista José de Alencar escreveu que o estreitatmento das relações comerciais e políticas dos dois países faria nascer "um grande pensamento de política americana, que no futuro venha a dirigir os destinos do Novo Mundo e a pôr um termo à intervenção européia”. A respeito de Meadde, que chegou a apresentar, formalmente, uma aliança internacional com o Império ancorada na existência comum da escravidão, um deputado brasileiro, elogiando essa "manifestação notável e rara", lamentou que o gabinete entendesse "que estava tudo feito com a prudente e delicada resposta que o monarca deu àquele enviado" 38 .

Não é difícil entender por que a resposta do governo foi "prudente e delicada", em vez de esfuziante e sonora. A memória da grave crise militar-diplomática de 1848-1851 com a Grã-Bretanha estava fresca, e os projetos norte-americanos de abertura do Vale Amazônico definitivamente não eram vistos com bons olhos, uma vez que o exemplo do que acontecera ao México, afinal, também era recente. Mesmo no Sul, a reabertura do tráfico não contava com as simpatias de grande parte dos advogados pró-escravistas, que argumentavam tratar-se de uma boutade arriscada para a segurança deles. No que estavam certos, aliás: a campanha e as açóes pró-tráfico lideradas por políticos e jornalistas da Carolina do Sul, em 1859, deram impulso, no Norte, ao Partido Republicano e, por conseguinte, à eleição presidencial de Abraham Lincoln ${ }^{39}$.

\section{A internacional escravista e seus limites}

As iniciativas para se construir uma internacional escravista ficaram a cargo de alguns dos mais ardorosos ideólogos da escravidão do Sul dos Estados Unidos. No plano doutrinário, apenas eles formularam a idéia de uma aliança hemisférica entre os senhores de escravos do Sul com os do Brasil e os de Cuba. Isto significa, então, que devemos concordar com a avaliação corrente de que, no conjunto das sociedades escravistas do Novo Mundo, apenas no Sul dos Estados Unidos se elaborou uma defesa da instituição em bases positivas? ${ }^{40}$

Nossa resposta é negativa. Houve, no Brasil e em Cuba, um conjunto amplo de idéias empregadas para defender o cativeiro: a noção de que a escravidão produzia cidadáos para o Brasil; a percepção contrária a certos pressuspostos do discurso da economia política - de que o trabalho escravo era mais produtivo que o livre; a necessidade de escravos em situação de fronteira aberta; a definição da escravidão como instrumento para a realização do progresso; a comparação da vida dos escravos com a dos trabalhadores livres urbanos na Grã-Bretanha; a censura do imperialismo britânico no extremo Oriente; a denúncia da miséria social dos irlandeses; a associação dos abolicionistas a movimentos radicais como o socialismo. Uma vez reconhecidas as semelhanças, é possível também indicar as diferenças, devidas a especificidades locais e a processos globais. Sem uma polarização continuada na arena política nacional como a que ocorreu nos Estados Unidos, os enunciadores brasileiros e hispano-cubanos não foram impelidos a uma articulação ideológica cada vez mais contundente, tal como o fizeram os porta-vozes sulistas. A contraprova é simples: onde a desconfiança em relação ao governo central apareceu, como 
no império espanhol, não tardou a formar-se um movimento de anexação que, na prática, não diferia do secessionismo que os fire-eaters alimentavam no Sul. Assim não com o Brasil, onde tal polarização em torno do cativeiro não chegou a empolgar parte significativa da sociedade, nem da elite política.

Longe de ser meramente formal, essa diferença pode ser mais bem compreendida se analisada à luz do sistema interestatal do século XIX: a natureza do discurso escravista do Sul e a projeção dos Estados Unidos no cenário internacional, com sua bem-sucedida política de incorporação de outros territórios no norte da América, cavaram no sistema interestatal um espaço de autonomia relativa vital à sobrevivência da escravidão em países periféricos como o Império Espanhol e o Brasil. E não podia ser de outro modo: quem podia ser levado a sério em Londres, quem dispunha de um Estado militarmente relevante (tendo derrotado a própria Grã-Bretanha duas vezes), quem fornecia o principal insumo da Revolução Industrial não eram os cafeicultores do Vale do Paraíba nem os donos de engenho do Ocidente de Cuba, mas os proprietários brancos, protestantes e membros de uma comunidade cultural inglesa que produziam algodão no sul dos Estados Unidos. Enquanto atores brasileiros e hispano-cubanos responderam a interlocutores imediatos de suas respectivas unidades políticas ou dialogaram com a Grä-Bretanha em canais quase exclusivamente diplomáticos, os atores sulistas procuraram operar também na arena internacional, publicando escritos para serem lidos fora do país na esperança de reverter a gradual construção de um consenso antiescravista no Ocidente.

Dito de outra maneira: a atuação ousada dos norte-americanos, ensejada por querelas locais, pela centralidade do algodão na economia-mundo industrial e pela posição internacional de seu Estado, foi um fator de estabilidade para a existência da escravidão em outros espaços, tornando menos necessárias, neles, formulaçóes discursivas e ideológicas tão contundentes, uma vez que inibia, no plano doméstico, articulações emancipacionistas e, no internacional, pressôes diplomáticas contra o tráfico ou a escravidão. Esse ponto demonstra, em resumo, a necessidade de abandonarmos as categorias interno/ externo na análise dos processos de formação dos Estados nacionais. Todos eles, afinal, se formaram no teatro unificado do moderno sistema mundo, simultaneamente global e local ${ }^{41}$.

Descendo aos casos concretos, basta lembrarmos como políticos escravistas do naipe de Honório Hermeto Carneiro Leão, Paulino José Soares de Sousa, Juan Bernardo O'Gavan e Wenceslao de VillaUrrutia apontaram a força escravista dos Estados Unidos para fazer frente a seus opositores no Império do Brasil e no império espanhol, ou mesmo à diplomacia britânica. O que fora percebido de pronto por esses defensores da escravidão acabaria, na segunda metade dos anos cinqüenta, sendo reconhecido também por um ressentido Palmerston. Cedo ou tarde, confessou ele, a Grä-Bretanha teria de ceder "passo a passo aos norte-americanos em quase toda questão disputada... exceto na manutenção de nossas províncias e de nossas ilhas caribenhas" ${ }^{\prime 2}$. Eis aí o ponto máximo do poder escravista dos Estados Unidos. Mas, se esse processo, visto com resignação em Londres, era a esperança de brasileiros e hispano-cubanos livres, também não deixava de apresentar limites quase insuperáveis.

A esperança, é claro, residia na garantia a seus regimes de trabalho. $\mathrm{Na}$ década que antecedeu a Guerra Civil, todas as potencialidades e os limites de uma internacional escravista estavam concentrados nos Estados Unidos. Com a máxima eficácia, o país centralizava as duas formas básicas para reproduzir em larga escala as relaçóes escravistas - o tráfico transatlântico negreiro ilegal e o crescimento vegetativo ampliado da populaçáo escrava. Tais açôes davam lastro ao que a vanguarda escravista dos Estados Unidos vinha propondo, no plano doutrinário, como uma internacional escravista, na qual os países em questão se ajudassem reciprocamente. A grande fraqueza dessa idéia, contudo, residiu justamente na incapacidade de seus propositores formalizarem-na de modo consistente; sua consecução limitou-se às práticas contingentes de cada espaço envolvido. Os grupos escravistas dos Estados Unidos, do Brasil e de Cuba nunca se reuniram em convençóes como as de 1840 e 1843, e tampouco encontraram um epicentro organizativo equivalente a Londres. Charleston, definitivamente, não foi capaz de atrair as classes senhoriais do Brasil e de Cuba. 
Esse fracasso se deveu a um duplo limite. O primeiro foi colocado pela própria divisão internacional do trabalho. Os militantes pró-escravistas do Sul dos Estados Unidos se lançaram à Guerra Civil impulsionados pela crença no poder do King Cotton, isto é, o prognóstico de que o conflito seria rapidamente resolvido em vista da dependência dos centros industriais do norte dos Estados Unidos e da Europa em relação à oferta sulista de algodáo. Dada a lógica de competiçáo entre as regiốes produtoras de artigos primários no mercado mundial, contudo, as redes da produção algodoeira mundial foram recompostas ainda durante a Guerra Civil, enfraquecendo, assim, a posição política e diplomática dos Estados Confederados da América. Isso ocorreu mesmo com um aliado em potencial: tal como o que se deu em outras regiōes da América Latina, da África e da Ásia, a retomada das exportaçôes algodoeiras do Brasil entre 1862 e 1865 contribuiu para a vitória das tropas de Lincoln ${ }^{43}$.

O segundo limite, relacionado diretamente ao primeiro, deriva do lugar da escravidáo negra no sistema interestatal do século XIX. Para fazer frente à Grã-Bretanha e à emergência do abolicionismo doméstico, a internacional escravista desenhada a partir do Sul dos Estados Unidos teve conteúdo inegavelmente imperialista, o que gerou fortes resistências na Espanha, em Cuba e no Brasil, onde os atores políticos tiveram de escolher, caminhando no fio da navalha, entre assegurar seus regimes de trabalho ou assegurar seus regimes de governo. Essas reticências foram igualmente estimuladas pela visão negativa que os racistas sulistas tinham dos povos latinos. $O$ internacionalismo antiescravista foi, neste sentido, muito mais eficaz: a militância antitráfico da Grá-Bretanha converteu-se em arma poderosa para a reorganização das relaçôes diplomáticas e dos espaços de fluxos globais, de uma forma que o Sul dos Estados Unidos jamais poderia sustentar, subordinado que estava àqueles mesmos fluxos.

O pró-escravismo militante sulista avaliou de modo equivocado a correlação internacional de forças em 1860-1861. A coexistência do cativeiro nos três espaços americanos criava um jogo de estabilidade reciprocamente auferida, mas não evoluiu a ponto de constituir uma plataforma para uma ação política concertada. Na hora da verdade, os Estados Confederados da América precisaram do reconhecimento de sua independência pela Grã-Bretanha, e não pelo Brasil ou Espanha, que não davam as cartas no sistema de consultas internacionais do século XIX. Indo para a guerra sozinhos, naufragaram, levando consigo as bases do Império do Brasil e do domínio espanhol sobre Cuba - além do sonho de uma escravidão negra perpétua.

\section{Notas}

${ }^{1}$ [ABREU E LIMA, José Inácio de]. As biblias falsificadas ou duas respostas ao sr. cônego Joaquim Pinto de Campos pelo christão velho. Recife: Typ. Commercial de G. H. de Mira, 1867, p. 326. A atribuição da obra está identificada em BLAKE, A. V. A. Sacramento. Diccionario Bibliographico Brazileiro. Rio de Janeiro: Imprensa Nacional, 1898, v. IV, p. 457.

${ }^{2}$ Acerca dos efeitos sobre o tráfico negreiro, ver MURRAY, David. Odious Commerce. Britain, Spainand the Abolition of the Cuban Slave Trade. Cambridge: Cambridge University Press, p. 298-326; da articulação do movimento antiescravista, SCHMIDT-NOWARA, Christopher. Empire and Antislavery: Spain, Cuba, and Puerto Rico, 1833-1874. Pittsburgh: University of Pittsburgh Press, 1999; da primeira guerra de Independência e da Lei Moret, GUERRA Y SÁNCHEZ, Ramiro. Manual de Historia de Cuba (1 ${ }^{\text {a }}$ ed: 1938). Havana: Editorial de Ciencias Sociales, 1971, p. 589-590, e SCOTT, Rebecca J. Emancipação escrava em Cuba: a transição para o trabalho livre, 1860-1899 (trad.port.; 1ª ed: 1985). Rio de Janeiro: Paz e Terra, 1991, p. 65-66.

${ }^{3} \mathrm{O}$ primeiro historiador brasileiro do século XX a estabelecer uma relação direta entre a Guerra Civil e a Lei do Ventre Livre foi BANDEIRA, Luiz A. Moniz. Presença dos Estados Unidos no Brasil (1ª ed., 1972). Rio de Janeiro: Civilização Brasileira, 2007, p. 155-161. Outros estudos que a mencionam são CONRAD, Robert. Os últimos anos da escravatura no Brasil, 1850-1888 (tradução portuguesa; $1^{a}$ ed.: 1972). Rio de Janeiro: Civilizaçáo Brasileira, 1975, p. 88-100; PENA, Eduardo Spiller. Pajens da casa imperial: jurisconsultos, escravidão e a lei de 1871. Campinas: Ed. Unicamp, 2001; CHALHOUB, Sidney. Machado de Assis, Historiador. São Paulo: Companhia das Letras, 2003, p. 139-142; e SALLES, Ricardo. E o Vale era o escravo: Vassouras, século XIX. Senhores e escravos no coração do Império. Rio de Janeiro: Civilização Brasileira, 2008, p. 79-110.

${ }^{4}$ DRESCHER, Seymour. Abolition: A History of Slavery and Antislavery. Cambridge: Cambridge University Press, 2009, p. $245-411$. 
${ }^{5}$ TOMICH, Dale. Through the Prism of Slavery: Labor, Capital, and World Economy. Boulder, Co: Rowman \& Littlefield, 2004 , p. 57.

${ }^{6}$ ARRIGHI, Giovanni. O longo século XX (trad. portuguesa; 1a ed: 1994). Rio de Janeiro: Contraponto/ São Paulo: Editora Unesp, 1996, p. 47-58.

${ }^{7}$ Sobre os motivos imediatos envolvidos na compra do território da Louisiana, FRY, Joseph A. Dixie looks abroad: The South and U.S. Foreign Relations, 1789-1973. Baton Rouge: Lousiana State University Press, 2002, p. 26-31; para a idéia de "potência imperial", MEINIG, D.W. The Shaping of America. A Geographical Perspective on 500 years of History. Volume II: Continental America, 1800-1867. Yale: Yale University Press, 1993, p. 23.

${ }^{8}$ MASON, Matthew. Slavery and Politics in the Early American Republic. Chapel Hill: The University of North Carolina Press, 2006, p. 87-105.

${ }^{9}$ Idem, p. 177-212.

${ }^{10}$ DAVIS, David Brion. Inhuman Bondage - the Rise and Fall of Slavery in the New World. Oxford: Oxford University Press, 2006, p. 279. O ultimo estudo monográfico da questão é o de FORBES, Robert Pierce. The Missouri Compromise and Its Aftermath. Chapell Hill: The University of North Carolina Press, 2007.

${ }^{11}$ ASHWORTH, John. Slavery, Capitalism, and Politics in the Antebellum Republic. Volume 1. Commerce and Compromise, 1820-1850. Cambridge: Cambridge University Press, 1995, p. 289-437.

12 Sobre a recepção do abolicionismo britânico nos Estados Unidos, RUGEMER, Edward Bartlett. The Problem of Emancipation. The Caribbean Roots of the American Civil War. Baton Rouge: Louisiana State University Press, 2008, p. 180-221. A respeito das articulaçóes internacionais do abolicionismo, MAYNARD, Douglas H. The World's Anti-Slavery Convention of 1840. The Mississippi Valley Historical Review, v. 47, n. 3, p. 452-471, 1960, e MCDANIEL, William Caleb. Our Country is the World: Radical American Abolitionists Abroad. PhD Thesis. Baltimore: The Johns Hopkins University, 2006, p. 28-105. Para uma análise da Carolina do Sul no período pré-bélico, SINHA, Manisha. The Counter-Revolution of Slavery. Politics and Ideology in Antebellum South Carolina. Chapel Hill: The University of North Carolina Press, 2000.

${ }^{13}$ GREESBERG, Kenneth. Masters and Statesmen. The Political Culture of American Slavery. Baltimore: The Johns Hopkins University Press, 1985, p. 106-123. Na década de 1850, contudo, ganhou força em círculos de proprietários de escravos livre-cambistas a crença na construção de uma harmonia política entre os dois países fundada na dependência econômica recíproca entre os teares da Revolução Industrial e as fibras de algodão dos campos sulistas. Ver SCHOEN, Brian. The Fragile Fabrico f Union: Cotton, Federal Politics, and the Global Origins of the Civil War. Baltimore: The John Hopkins University Press, 2009, p. 197-259.

${ }^{14}$ BERBEL, Márcia, MARQUESE, Rafael \& PARRON, Tâmis. Escravidão e política: Brasil e Cuba, c. 1780-1850. São Paulo: Hucitec, 2010.

${ }^{15}$ Annaes do Parlamento Brazileiro: Câmara dos Srs. Deputados (doravante, ACD). Rio de Janeiro: Typ. da Viúva Pinto e Filho, 1884, seção de 17 de julho de 1839, t. II, p. 336-337.

${ }^{16}$ Sobre a confluência entre trabalhadores e livre-cambistas, DRESCHER, Seymour. The Mighty Experiment: Free Labor versus Slavery in British Emancipation. New York: Oxford University Press, 2002, p. 158-178.

${ }^{17}$ O Parlamento francês, contudo, se recusaria a ratificar o Tratado.

${ }^{18}$ MAYNARD, Douglas H. The World's Anti-Slavery Convention of 1840, op. cit.; MCDANIEL, William Caleb. Our Country is the World: Radical American Abolitionists Abroad, op. cit.; MITTON, Steven Heath. The Free World Confronted: the Problem of Slavery and Progress in American Foreign Relations, 1833-1844. PhD Thesis. Baton Rouge: Louisiana State University, 2005; RUGEMER, Edward Bartlett. The Problem of Emancipation. The Caribbean Roots of the American Civil War, op. cit.

${ }^{19}$ HORNE, Gerald. The Deepest South: The United States, Brazil, and the African Slave Trade. New York: New York University Press, 2007; e RUGEMER, Edward B. The Problem of Emancipation, op. cit. Antes, já haviam chamado a atenção para o tema LUZ, Nícia Villela. A Amazônia para os negros americanos. As origens de uma controvérsia internacional. Rio de Janeiro: Saga, 1968, e WRIGHT, Antonia Fernanda de Almeida. Desafio americano à preponderância britânica no Brasil, 1808-1850. São Paulo: Cia. Editora Nacional/Brasília: Instituto Nacional do Livro, 1978, p. 221-248.

${ }^{20}$ MITTON, Steven H. The Free World Confronted: the Problem of Slavery and Progress in American Foreign Relations, 1833-1844, op. cit., p. 22-55.

${ }^{21}$ Parecer de Villa Urrutia, de 25 de março de 1842, reproduzido em TARDIEU, Jean-Pierre. “Dominar o morir”: en torno al reglamento de esclavos de Cuba (1841-1866). Frankfurt: Vervurt; Madrid: Iberoamericana, 2003, p. 257.

${ }^{22}$ ACD, Sessão de 6 de fevereiro de 1843, p. 542-543.

${ }^{23}$ Ver, por exemplo, [PEREIRA da SILVA, J. M.]. Inglaterra e Brasil-tráfego de escravos. Por um Deputado. Rio de Janeiro: Typographia do Brasil, de J. J. da Rocha, 1845; e discursos parlamentares de Bernardo Pereira de Vasconcelos reproduzidos em Anais do Senado (doravante, AS), sessóes de 25 a 27 de abril de 1843, p. 346-396. Para o estabelecimento da autoria do 
primeiro e uma análise do contexto enunciativo do segundo, ver PARRON, Tâmis. A política da escravidão no Império do Brasil. Rio de Janeiro: Civilização Brasileira, 2011, p. 208-219 e 223-230.

24 "Ofícios da missão especial em Londres, 1843, de José de Araújo Ribeiro a Paulino José Soares de Souza, 23 de novembro de 1843 e 28 de dezembro de 1843”, Arquivo Histórico do Itamaraty, códice 271/4/6. Ribeiro diz ter encontrado um agente norte-americano vindo de Paris e ex-redator de um jornal em Washington que tinha sido encarregado de discutir sobre a escravidão negra com quem achasse conveniente. Duff Green se encaixa perfeitamente nesse perfil: fora redator do US Telegraph, de Washington, passara uma temporada em Paris e encontrava-se então em Londres, para onde fora enviado, por Abel Uphser, para informar o gabinete norte-americano de qualquer política européia que pudesse afetar a escravidão nos Estados Unidos. A esse respeito, ver MITTON, S. H. The Free World Confronted, op. cit., p. 63-67.

25 "Instructions to U. S. Ministers", série IV, J. C. Calhoun a Henry Wise, 20 de maio de 1844, apud WRIGHT, Antonia F. P. de A. Desafio americano à preponderância britânica no Brasil, 1808-1850, op. cit., p. 239-241. Grifos originais.

${ }^{26}$ AS, Sessão de 3 de julho de 1845, p. 217.

${ }^{27}$ MARQUES, João Pedro. Os sons do silêncio: o Portugal de Oitocentos e a abolição do tráfico de escravos. Lisboa: Imprensa de Ciências Sociais, 1999.

${ }^{28}$ FEHRENBACHER, Don E. The Slaveholding Republic. An Account of the United States Government's Relations to Slavery (Completed and edited by Ward M. McAfee). Oxford: Oxford University Press, 2001, p. 156-202; MARQUES, Leonardo. A participação norte-americana no tráfico transatlântico de escravos para os Estados Unidos, Cuba e Brasil. História: Questóes \& Debates, n. 52, p. 87-113, jan./jun.2010.

${ }^{29}$ A esse respeito, ver BERBEL, M., MARQUESE, R. \& PARRON, T. Escravidáo e política: Brasil e Cuba, c. 1780-1850, op. cit., p. 276-303.

${ }^{30}$ Apud MURRAY, David. Odious Commerce. Britain, Spain and the Abolition of the Cuban Slave Trade, op. cit., p. $230-231$.

${ }^{31}$ Ver SLENES, Robert. The Brazilian Internal Slave Trade, 1850-1888: Regional Economies, Slave Experience, and the Politics of a Peculiar Market. In: JOHNSON, Walter (Org.). The Chattel Principle: Internal Slave Trades in the Americas. London: Yale University Press, 2004. p. 325-270.

32 Cf. PARRON, Tâmis. A política da escravidão no Império do Brasil, op. cit., p. 245-9.

${ }^{33}$ MARQUESE, Rafael de Bivar. Feitores do corpo, missionários da mente. Senhores, letrados e o controle dos escravos nas Américas, 1660-1860. São Paulo: Companhia das Letras, 2004, p. 286-288.

34 "Extrato de um Parecer da Seção dos Negócios do Império do Conselho de Estado, de 4 de Fevereiro de 1853, sobre um plano para a introdução de colonos no Império”, Instituto Histórico e Geográfico Brasileiro (IHGB), lata 824, doc. 18.

35 Sobre a especulação fundiária provocada pela expansão das ferrovias, ver SCHOEN, Brian. The Fragile Fabric of Union: Cotton, Federal Politics, and the Global Origins of the Civil War, op. cit., p. 212.

${ }^{36}$ MAY, Robert E. The Southern Dream of a Caribbean Empire, 1854-1861. Gainesville: University Press of Florida, 2002, p. 46-76.

${ }^{37}$ TAKAKI, Ronald T. A Pro-Slavery Crusade. The Agitation to Reopen the African Slave Trade. New York: The Free Press, 1971.

${ }^{38}$ As citações foram, respectivamente, extraídas de ALENCAR, José de. Ao correr da pena. Org. de João Roberto de Faria. São Paulo: Martins Fontes, 2004, p. 336, e de ACD, Sessão de 4 de agosto de 1858, p. 36.

${ }^{39}$ Sobre a Amazônia, LUZ, Nícia V. A Amazônia para os negros; a respeito da Carolina do Sul e Partido Republicano, SINHA, M. The Counter-Revolution of Slavery. Politics and Ideology in Antebellum South Carolina, op. cit., p. 173-180.

${ }^{40}$ Mesmo especialistas que não estão presos à visão paroquial que marca grande parte da historiografia norte-americana sobre a escravidão esposam essa opinião. Joseph Miller, por exemplo, afirma que "os proprietários de escravos dos Estados Unidos foram os únicos senhores [na história da escravidão negra no Novo Mundo] que edificaram uma defesa sistemática da escravidão". Em regióes como o Império do Brasil e a colônia de Cuba, prossegue o raciocínio, não teria ocorrido a elaboração de argumentos que defendessem em bases positivas a instituição. MILLER, Joseph C. Stratégies de marginalité. Une approche historique de l'utilisation des êtres humains et des idéologies de l'esclavage: progéniture, píété, protection personnelle et prestige-produit et profits des propriétaires. In: HENRIQUES, Isabel Castro \& SALA-MOLINS, Louis (Orgs.). Déraison, esclavage et droit. Les fondements idéologiques et juridiques de la traite négrière et de l'esclavage. Paris: Éditions Unesco, 2002, p. 126.

${ }^{41}$ A respeito desse problema metodológico, ver o texto seminal de HOPKINS, T. K. The Study of the Capitalist World-Economy: Some Introductory Considerations. In: K.HOPKINS, T. \& WALLERSTEIN, I., (Orgs.). World-Systems Analysis. Theory and Methodology. Beverly Hills: Sage Publications, 1982, p. 9-38.

${ }^{42}$ Apud SCHOEN, Brian. The Fragile Fabric of Union: Cotton, Federal Politics, and the Global Origins of the Civil War, op. cit., p. 218.

${ }^{43}$ Sobre a crença no King Cotton e a reconfiguração da rede mundial de abastecimento de algodão, ver, respectivamente, SCHOEN, Brion. The Fragile Fabric of Union: Cotton, Federal Politics, and the Global Origins of the Civil War, op. cit., e BECKERT, Sven. Emancipation and Empire: Reconstructing the Worldwide Web of Cotton Production in the Age of the American Civil War. The American Historical Review, v. 105, n. 5, p. 1405-1438, 2004. 


\section{Referências bibliográficas}

[ABREU E LIMA, José Inácio de]. As biblias falsificadas ou duas respostas ao sr. cônego Joaquim Pinto de Campos pelo christâo velho. Recife: Typ. Commercial de G. H. de Mira, 1867.

ALENCAR, José de. Ao correr da pena. Org. de João Roberto de Faria. São Paulo: Martins Fontes, 2004. ARRIGHI, Giovanni. O longo século XX. Rio de Janeiro: Contraponto; São Paulo: Editora Unesp, 1996. Trad. portuguesa. $1^{\text {a }}$ ed., 1994.

ASHWORTH, John. Slavery, Capitalism, and Politics in the Antebellum Republic. Volume 1. Commerce and Compromise, 1820-1850. Cambridge: Cambridge University Press, 1995.

BANDEIRA, Luiz A. Moniz. Presença dos Estados Unidos no Brasil. Rio de Janeiro: Civilização Brasileira, 2007. $1^{\text {a }}$ ed., 1972.

BECKERT, Sven. Emancipation and Empire: Reconstructing the Worldwide Web of Cotton Production in the Age of the American Civil War. The American Historical Review, v. 105, n. 5, p. 1405-1438, 2004.

BERBEL, Márcia; MARQUESE, Rafael; PARRON, Tâmis. Escravidão e política. Brasil e Cuba, c.17901850. São Paulo: Hucitec, 2010.

BLAKE, A. V. A. Sacramento. Diccionario Bibliographico Brazileiro. Rio de Janeiro: Imprensa Nacional, 1898 , v. IV.

CHALHOUB, Sidney. Machado de Assis, Historiador. São Paulo: Companhia das Letras, 2003.

CONRAD, Robert. Os últimos anos da escravatura no Brasil, 1850-1888. Rio de Janeiro: Civilização Brasileira, 1975. Portuguese Translation. 1st ed., 1973.

DAVIS, David Brion. Inhuman Bondage - the Rise and Fall of Slavery in the New World. Oxford: Oxford University Press, 2006.

DRESCHER, Seymour. Abolition: A History of Slavery and Antislavery. Cambridge: Cambridge University Press, 2009.

The Mighty Experiment: Free Labor versus Slavery in British Emancipation. New York:

Oxford University Press, 2002.

ELTIS, David. Economic Growth and the Ending of the Transatlantic Slave Trade. New York: Oxford University Press, 1987.

FEHRENBACHER, Don E. The Slaveholding Republic. AnAccount of the United States Government's Relations to Slavery (Completed and edited by Ward M. McAfee). Oxford: Oxford University Press, 2001.

FORBES, Robert Pierce. The Missouri Compromise and Its Aftermath. Chapell Hill: The University of North Carolina Press, 2007.

FRY, Joseph A. Dixie looks abroad: The South and U.S. Foreign Relations, 1789-1973. Baton Rouge: Lousiana State University Press, 2002.

GREENSBERG, Kenneth. Masters and Statesmen. The Political Culture of American Slavery. Baltimore: The Johns Hopkins University Press, 1985.

GUERRA Y SÁNCHEZ, Ramiro. Manual de Historia de Cuba (1a Ed: 1938). Havana: Editorial de Ciencias Sociales, 1971. 
HOPKINS, T.K. The Study of the Capitalist World-Economy: Some Introductory Considerations. In: HOPKINS, T.K. \& WALLERSTEIN, I. (Orgs.). World-Systems Analysis. Theory and Methodology. Beverly Hills: Sage Publications, 1982. p. 9-38.

HORNE, Gerald. The Deepest South: The United States, Brazil, and the African Slave Trade. New York: New York University Press, 2007.

LUZ, Nícia Villela. A Amazônia para os negros americanos. As origens de uma controvérsia internacional. Rio de Janeiro: Saga, 1968.

MARQUES, João Pedro. Os sons do silêncio: o Portugal de Oitocentos e a abolição do tráfico de escravos. Lisboa: Imprensa de Ciências Sociais, 1999.

MARQUES, Leonardo. A participação norte-americana no tráfico transatlântico de escravos para os Estados Unidos, Cuba e Brasil. História: Questôes \& Debates, n. 52, p. 87-113, jan./jun.2010.

MARQUESE, Rafael de Bivar. Feitores do corpo, missionários da mente: senhores, letrados e o controle dos escravos nas Américas, 1680-1860. São Paulo: Companhia das Letras, 2004.

MASON, Matthew. Slavery and Politics in the Early American Republic. Chapel Hill: The University of North Carolina Press, 2006.

MAY, Robert E. The Southern Dream of a Caribbean Empire, 1854-1861. Gainesville: University Press of Florida, 2002.

MAYNARD, Douglas H. The World's Anti-Slavery Convention of 1840. The Mississippi Valley Historical Review, v. 47, n. 3, p. 452-471, 1960.

MCDANIEL, William Caleb. Our Country is the World: Radical American Abolitionists Abroad. PhD Thesis. Baltimore: The Johns Hopkins University, 2006.

MEINING, D. W. The Shaping of America. A Geographical Perspective on 500 years of History. Volume II: Continental America, 1800-1867. Yale: Yale University Press, 1993.

MILLER, Joseph C. Stratégies de marginalité. Une approche historique de l'utilisation des êtres humains et des idéologies de l'esclavage: progéniture, piété, protection personnelle et prestige - produit et profits des propriétaires. In: HENRIQUES, Isabel Castro \& SALA-MOLINS, Louis (Orgs.). Déraison, esclavage et droit. Les fondements idéologiques et juridiques de la traite négrière et de l'esclavage. Paris: Éditions Unesco, 2002. p. 105-160.

MITTON, Steven Heath. The Free World Confronted: the Problem of Slavery and Progress in American Foreign Relations, 1833-1844. PhD Thesis. Baton Rouge: Louisiana State University, 2005.

MURRAY, David. Odious Commerce. Britain, Spain and the Abolition of the Cuban Slave Trade. Cambridge: Cambridge University Press, 1980.

PAQUETTE, Robert. Sugar is made with Blood: The Conspiracy of La Escalera and the Conflict between Empires over Slavery in Cuba. Middletown, Connecticut: Wesleyan University Press, 1988.

[PEREIRA da SILVA, J. M.]. Inglaterra e Brasil - tráfego de escravos. Por um Deputado. Rio de Janeiro: Typographia do Brasil, de J. J. da Rocha, 1845.

PARRON, Tâmis. A política da escravidão no Império do Brasil, 1826-1865. Rio de Janeiro: Civilização Brasileira, 2011.

PENA, Eduardo Spiller. Pajens da casa imperial: jurisconsultos, escravidão e a lei de 1871. Campinas: Ed. Unicamp, 2001. 
RUGEMER, Edward Bartlett. The Problem of Emancipation. The Caribbean Roots of the American Civil War. Baton Rouge: Louisiana State University Press, 2008.

SALLES, Ricardo. E o Vale era o escravo: Vassouras, século XIX. Senhores e escravos no coração do Império. Rio de Janeiro: Civilização Brasileira, 2008.

SCHMIDT-NOWARA, Christopher. Empire and Antislavery: Spain, Cuba, and Puerto Rico, 18331874. Pittsburgh: University of Pittsburgh Press, 1999.

SCHOEN, Brian. The Fragile Fabric of Union: Cotton, Federal Politics, and the Global Origins of the Civil War. Baltimore: The John Hopkins University Press, 2009.

SCOTT, Rebecca J. Emancipação escrava em Cuba: a transição para o trabalho livre, 1860-1899. Rio de Janeiro: Paz e Terra, 1991. Portuguese Translation, $1^{\text {st }}$. ed., 1985.

SINHA, Manisha. The Counter-Revolution of Slavery. Politics and Ideology in Antebellum South Carolina. Chapel Hill: The University of North Carolina Press, 2000.

SLENES, Robert. The Brazilian Internal Slave Trade, 1850-1888: Regional Economies, Slave Experience, and the Politics of a Peculiar Market. In: JOHNSON, Walter (Org.). The Chattel Principle: Internal Slave Trades in the Americas. London: Yale University Press, 2004. p. 325-270.

TAKAKI, Ronald T. A Pro-Slavery Crusade. The Agitation to Reopen the African Slave Trade. New York: The Free Press, 1971.

TARDIEU, Jean-Pierre. "Dominar o morir": en torno al reglamento de esclavos de Cuba (1841-1866). Frankfurt: Vervurt; Madrid: Iberoamericana, 2003.

TOMICH, Dale. Through the Prism of Slavery: Labor, Capital, and World Economy. Boulder, Co: Rowman \& Littlefield, 2004.

TURLEY, David. The Culture of English Antislavery, 1780-1860. London: Routledge, 1991.

WRIGHT, Antonia Fernanda de Almeida. Desafio americano à preponderância britânica no Brasil, 1808-1850. São Paulo: Cia. Editora Nacional/Brasília: Instituto Nacional do Livro, 1978. 